\title{
Tinggalan Megalitik Kecamatan Parado, Kabupaten Bima, Nusa Tenggara Barat: Kajian Bentuk dan Fungsi
}

\author{
Akbar Eka Nugraha ${ }^{*}$, Rochtri Agung Bawono ${ }^{2}$, I Wayan Srijaya ${ }^{3}$ \\ ${ }^{[123]}$ Prodi Arkeologi Fakultas Ilmu Budaya \\ ${ }^{1}$ [akbar.e.nugraha@gmail.com] ${ }^{2}$ [rabawono@gmail.com] ${ }^{3}$ [srijaya59@yahoo.com] \\ *Corresponding Author
}

\begin{abstract}
Sumbawa Islands is one of Indonesian islands with many variety of archaeological remains. These archaeological remains are generally from the megalithic culture. These remains almost spread all over Sumbawa Islands, especially in Parado District, Bima Regency, West Nusa Tenggara. Lack of research in this region is one of the reasons for choosing it. The aim of this research is to know the form, function and relation of the megalithic remains in Parado District with the kind of megalithic remain in Sumbawa Island.This research is an exploration research which uses some methods such as data collection, analysis and theory in order to solve the question. The method of data collection specifically includes observation, interviews and a literature review. The next step is processing the data with morphological, stylistic, contextual and comparative analysis. The theories which are used for solving the question are structural functional and religious theories. The result from analyzing the form and function of megalithic remains shows that these megalithic remains were used for profane and sacred things. The similarities between the form of megalithic remains in Parado District with the kind of megalithic remains in Sumbawa Islands shows that these megalithic remains have a connection. This connection shows that megalithic remains in Sumbawa Islands were from the same culture and periods.
\end{abstract}

Keywords: Sumbawa Islands, Megalithic Remain, Form and Function

\begin{abstract}
Abstrak
Kepulauan Sumbawa merupakan salah satu kepulauan di Indonesia dengan aneka ragam tinggalan arkeologi. Tinggalan arkeologi tersebut pada umumnya berupa tinggalan dari kebudayaan megalitik. Tinggalan ini tersebar hampir di seluruh Kepulauan Sumbawa, khususnya di Kecamatan Parado, Kabupaten Bima, Nusa Tenggara Barat. Kurangnya penelitian di wilayah ini menjadi salah satu alasan pemilihan lokasi penelitian. Tujuan penelitian ini untuk mengetahui bentuk dan fungsi serta hubungan tinggalan megalitik di Kecamatan Parado dengan tinggalan megalitik sejenis di Kepulauan Sumbawa.Penelitian ini merupakan penelitian eksplorasi dengan menggunakan beberapa metode pengumpulan data, analisis data dan teori untuk memecahkan permasalahan. Metode pengumpulan data yaitu meliputi observasi, wawancara dan studi kepustakaan. Tahap selanjutnya yaitu pengolahan data dengan menggunakan analisis morfologi, stilistik, kontekstual dan komparatif. Teori yang digunakan untuk menyelesaikan permasalahan penelitian ini yaitu teori struktural fungsional dan teori religi. Hasil dari analisis bentuk dan fungsi tinggalan megalitik yang ditemukan menunjukkan bahwa tinggalan megalitik tersebut digunakan sebagai benda profan dan sakral. Kesamaan bentuk antara tinggalan megalitik di Kecamatan Parado dengan tinggalan megalitik sejenis yang berada di Kepulauan Sumbawa menunjukkan bahwa tinggalan megalitik tersebut saling berhubungan satu sama lain. Hubungan ini menunjukan bahwa tinggalan megalitik di Kepulauan Sumbawa berasal dari satu budaya dan periode yang sama.
\end{abstract}

Kata kunci: Kepulauan Sumbawa, Tinggalan Megalitik, Bentuk dan Fungsi 


\section{Latar Belakang}

Pulau Sumbawa merupakan salah satu pulau di Provinsi Nusa Tenggara Barat yang memiliki aneka ragam tinggalan Masa Prasejarah. Bentukbentuk tinggalan dari Masa Prasejarah, khususnya tradisi megalitik di wilayah ini yaitu kubur batu, teras berundak, lumpang batu, menhir, dolmen, lesung batu, gerabah, kereweng, dan keramik (Sunarya, 2006: 37 ; Kusumawati dan Gede, 2009: 18 ; Kusumawati, 2009a: 86 - 87 , 2009b: 140 - 141, 2010: 529). Kompleksnya tinggalan megalitik tersebut menunjukkan bahwa tradisi megalitik di Pulau Sumbawa berlangsung cukup lama. Beberapa situs diasumsikan sebagai situs masa prasejarah akhir yang berlanjut ke masa Hindu, salah satu contoh Situs Dorobata. Pada situs ini ditemukan lumpang batu yang merupakan tinggalan universal dan pada umumnya terdapat di situs-situs prasejarah. Selain lumpang batu, konsep yang melandasi bangunan Candi Dorobata adalah konsep teras berundak yang merupakan konsep asli Indonesia dengan unsur Hindu. (Ambarawati, 2012: 255 - 264).

Penelitian terhadap sumberdaya arkeologi, khususnya tinggalan tradisi megalitik, yang berada di Pulau Sumbawa dilakukan secara bertahap. Penelitian terhadap pola hias kubur batu dilakukan Ayu Kusumawati (1999) di tiga situs yang berada di Sumbawa yaitu Situs Lutuk Peti, Situs Tarakin, dan Situs Batutering, Kabupaten Sumbawa. Pahatan yang menjadi pola hias kubur batu tersebut yaitu pahatan perahu, pahatan manusia kangkang, pahatan binatang berupa anjing dan buaya, serta pahatan topeng (Kusumawati, 1999: 14 21). Penelitian lain dilakukan oleh Balai Arkeologi Denpasar di beberapa lokasi seperti di Situs Ta'a, Kecamatan Kempo, dan situs-situs di Kecamatan Hu'u, Kabupaten Dompu.
Penelitian terhadap tinggalan megalitik di Pulau Sumbawa tidak hanya terhenti sampai beberapa lokasi. Penelitian pada tahun 2008 merupakan penelitian awal di Kecamatan Donggo, Kabupaten Bima yang dilakukan oleh Balai Arkeologi Denpasar. Hasil penelitian tersebut berupa sumberdaya arkeologi yang berasal dari tradisi prasejarah khususnya tradisi megalitik. Peninggalan tradisi megalitik tersebut diantaranya berupa temuan lepas seperti pecahan-pecahan gerabah yang ditemukan di atas permukaan tanah dan kubur dolmen, lumpang batu, teras berundak, serta bejana batu (kalamba) atau dalam arkeologi disebut dengan istilah stone vat (Kusumawati dan Gede, 2009: 1).

Kurangnya penelitian arkeologi di Kabupaten Bima mengakibatkan sedikitnya pengetahuan tentang sumberdaya arkeologi di wilayah ini, khususnya tinggalan dari masa megalitik. Salah satu lokasi dengan beragam jenis tinggalan megalitik adalah Kecamatan Parado, Kabupaten Bima, Nusa Tenggara Barat. Tinggalan megalitik di kecamatan ini tersebar hampir di setiap desa, namun kegiatan penelitian arkeologi belum pernah dilakukan oleh Balai Arkeologi Denpasar dan Balai Pelestari Cagar Budaya Bali sehingga perlu adanya penelitian eksplorasi di Kecamatan Parado, Kabupaten Bima.

\section{Pokok permasalahan}

Berdasarkan uraian di atas, maka permasalahan yang dikaji penulis dalam penelitian ini dirumuskan sebagai berikut.

a. Bagaimana bentuk dan fungsi tinggalan megalitik yang terdapat di Kecamatan Parado pada masa lalu?

b. Bagaimanakah hubungan tinggalan megalitik di Kecamatan Parado dengan tinggalan megalitik sejenis di Kepulauan Sumbawa? 


\section{Tujuan Penelitian}

Adapun tujuan penelitian ini adalah sebagai berikut.

a. Mendeskripsikan bentuk dan fungsi tinggalan megalitik yang terdapat di Kecamatan Parado pada masa lalu.

b. Mendeskripsikan hubungan tinggalan megalitik di Kecamatan Parado dengan tinggalan megalitik sejenis di Sumbawa.

\section{Metode Penelitian}

Jenis penelitian ini dirancang sebagai penelitian eksplorasi dan eksplanasi yang menggunakan metode kualitatif. Penelitian eksplorasi adalah penelitian dengan tujuan menjajagi data arkeologi yang ada dalam suatu ruang tertentu atau untuk mencari kemungkinan adanya hubungan antar variabel yang diteliti, sedangkan penelitian eksplanasi adalah penelitian dengan tujuan memberikan penjelasan tentang gejala yang diteliti dengan menerapkan dalil, metode, atau teori tertentu. Adapun metode kualitatif yang dimaksud yaitu metode yang menghasilkan data deskriptif berupa data tertulis dari objek yang diamati (Simanjuntak, 1999: 10 ; Endraswara, 2003: 14).

Lokasi penelitian ini dilakukan di Situs Doro Asi, Situs Wadu Wawi, Situs Wawo Saruhu, Situs Wawo Widu, Situs Wo'o Peto dan Situs Tabe Mariwu yang berada di Kecamatan Parado, Kabupaten Bima, Nusa Tenggara Barat. Pemilihan lokasi ini dilakukan dengan pertimbangan yaitu (1) penelitian arkeologi ini merupakan penelitian pertama kali di Kecamatan Parado, atau belum pernah ada kajian ilmiah untuk tinggalan arkeologi di lokasi ini dan (2) tinggalan megalitik dari keenam situs tersebut penulis anggap telah mewakili karakter dari tinggalan megalitik yang berada di Kecamatan Parado.

Teknik pengumpulan data yang digunakan dalam penelitian ini yaitu observasi, studi pustaka, dan wawancara dari informan yang bersangkutan di lokasi penelitian yaitu Kecamatan Parado, Kabupaten Bima.

Penelitian ini menggunakan analisis morfologi, analisis stilistik, analisis kontekstual, dan analisis komparatif. Penerapan analisis morfologi yaitu dengan cara mengamati bentuk tinggalan yang berada di setiap situs yang telah disebutkan. Analisis stilistik dilakukan dengan cara mengamati variabel-variabel yang berupa ragam hias seperti relef-relief. Analisis kontekstual diterapkan dengan cara mengamati letak satu tinggalan dengan tinggalan lain yang berada pada satu situs, sedangkan analisis komparatif dilakukan dengan cara membandingkan tinggalan megalitik yang berada di Kecamatan Parado dengan tinggalan megalitik sejenis yang terdapat di beberapa wilayah di Kepulauan Sumbawa.

\section{Hasil dan Pembahasan}

Situs-situs megalitik di Kecamatan Parado sebagian besar berada di puncak perbukitan dan hutan-hutan alam. Beberapa diantaranya terletak di dekat pemukiman warga. Situs-situs ini diketahui oleh warga yang pada umumnya bekerja sebagai petani dan pemburu.

\section{a. Bentuk dan Fungsi Tinggalan Megalitik Kecamatan Parado}

Secara umum bentuk dan fungsi tinggalan megalitik yang terdapat di Kecamatan Parado memiliki kesamaan dengan tinggalan megalitik yang berada di Kepulauan Sumbawa lainnya. Tinggalan megalitik tersebut antara lain Kubur atau Bejana Batu yang disebut sebagai Widu, Lumpang Batu, Arca Megalitik, Relief, Dolmen, Parabo, Tabe, dan Fragmen Widu. Tinggalan megalitik di kecamatan ini bersifat Death Monument, dalam artian sudah tidak 
difungsikan sebagaimana tinggalan tersebut dibuat.

Kubur atau bejana batu yang disebut sebagai widu tersebar di beberapa lokasi antara lain Situs Doro Asi, Situs Wadu Wawi, Situs Wawo Widu, dan Situs Wo'o Peto. Widu di Kecamatan Parado dapat dikategorikan menjadi empat tipe antara lain sebagai berikut.

a. Widu tipe 1 merupakan wadah kubur bejana batu berbentuk lingkaran pada batuan monolit yang dibuat dengan cara melubangi batuan tersebut.

b. Widu tipe 2 sama halnya dengan widu tipe 1 yang dibuat dengan cara melubangi batuan monolit, hanya saja lubang widu tipe 2 berbentuk persegi panjang.

c. Widu tipe 3 merupakan batuan monolit yang dibentuk menyerupai silinder.

d. Widu tipe 4 merupakan batuan-batuan yang disusun pada liang sehingga menyerupai sumur

Tinggalan serupa juga ditemukan di situs-situs megalitik Kecamatan Donggo, Kabupaten Bima dan Kecamatan Hu'u, Kabupaten Dompu. Sisa-sisa penguburan memang tidak ditemukan pada widuwidu di Kecamatan Parado, namun pada beberapa situs, sebagai contoh Situs So Langgodu, Kecamatan Hu'u, memiliki benda-benda yang umumnya difungsikan sebagai bekal kubur. Benda-benda tersebut antara lain belati besi dan keramik (Kusumawati, 2010: 524; Kusumawati dkk, 2013: 9-29), sehingga widu-widu di Kecamatan Parado diasumsikan memiliki fungsi yang sama yaitu sebagai wadah kubur.

Tinggalan megalitik selanjutnya yaitu Lumpang Batu. Tinggalan ini terdapat di Situs Doro Asi dan Situs Wadu Wawi. Lumpang batu di Situs Doro Asi memiliki keunikan bentuk yaitu menyerupai telapak kaki. Masyarakat Kecamatan Parado menyebutnya sebagai
Kopa Bibano atau Telapak Kaki Bibano. Tinggalan berupa tapak kaki juga ditemukan di Situs Kopa'ncui dan Situs Doromanto, Kecamatan Hu'u, Kabupaten Dompu. (Yuliati, 2004: 83). Berdasarkan hasil wawancara dengan masyarakat sekitar, Kopa tersebut difungsikan sebagai penanda wilayah pada masa lalu sehingga fungsi lumpang batu Kopa Bibano pada masa lalu diperkirakan sebagai penanda wilayah. Berbeda halnya dengan Kopa Bibano, Lumpang batu di Situs Wadu Wawi berbentuk menyerupai cobek. Tidak banyak informasi yang didapatkan dari lumpang batu yang berada di Situs Wadu Wawi selain bahwa situs tersebut merupakan tempat pemujaan masyarakat Parado masa lalu. Lumpang batu merupakan tinggalan universal yang hampir ditemukan di situs-situs pemujaan masa megalitik, sehingga berdasarkan konteksnya lumpang batu di Situs Wadu Wawi difungsikan untuk menumbuk biji-bijian atau sesuatu yang perlu ditumbuk sebagai sarana yang bersifat sakral.

Tinggalan megalitik lain yaitu Arca Megalitik yang terdapat di Situs Wadu Wawi. Arca Megalitik Wadu Wawi adalah batuan monolit yang dipahat dan dibentuk menyerupai hewan. Masyarakat sekitar menyebut arca tersebut sebagai Wadu Wawi, berasal dari kata Wadu yang berarti batu dan Wawi yang berarti babi. Arca ini memiliki 3 relief di bagian penumpu. Relief-relief tersebut antara lain relief manusia kangkang, relief perahu, dan relief anjing. Selain widu, arca dan lumpang batu, tinggalan megalitik di situs ini yaitu Dolmen. Arca Megalitik Wadu Wawi difungsikan sebagai media penghormatan pada masa lalu. Hal ini didasarkan pada bentuk, konteks arca, dan relief-reliefnya. Relief pahatan manusia kangkang merupakan personifikasi arwah dari individu yang telah meninggal, sedangkan relief perahu merupakan simbol dari perahu arwah 
yang mengantar arwah individu tersebut ke dunia arwah. Relief anjing merupakan simbol dari hewan penjaga yang mengantar arwah individu tersebut. Adapun dolmen Situs Wadu Wawi jika dilihat berdasarkan konteksnya difungsikan menaruh sesaji pada masa lalu.

Parabo merupakan tinggalan berupa susunan batu yang berbentuk kotak memanjang dan di dalamnya terdapat batuan-batuan lain yang disusun saling berdampingan. Menurut informasi masyarakat setempat, batuan-batuan yang terdapat di dalam Parabo memiliki nilai magis seperti contoh ketika kita mengambil dan membawa salah satu batuan, maka batuan tersebut akan kembali ke dalam Parabo tersebut dengan sendirinya. Tinggalan ini mengingatkan akan kepercayaan Parafu di Kepulauan Sumbawa, sehingga Parabo penulis asumsikan sebagai salah satu benda yang disebut sebagai Parafu atau benda yang memiliki roh. Kepercayaan akan Parafu ini masih dapat ditemukan di Bima hingga sekarang.

Tinggalan Tabe terdapat di Situs Wo'o Peto dan Situs Tabe Mariwu. Bentuk dari tabe ini dapat dapat dikategorikan menjadi 2 tipe yaitu sebagai berikut.

a. Tabe tipe1 merupakan tinggalan megalitik yang terbuat dari batuan monolit dan dibentuk menyerupai wajan besar.

b. Tabe tipe 2 dibentuk menyerupai limas dengan 8 lubang di bagian yang mengerucut.

Tabe merupakan penyebutan lokal terhadap tinggalan yang berbentuk menyerupai wajan. Fungsi dari tabe-tabe tersebut yaitu sebagai tutup dari wadah kubur atau widu sebagaimana halnya tutup-tutup bejana batu yang terdapat di Situs Karombo Dudu, Kecamatan Donggo, Kabupaten Bima.

\section{b. Hubungan Tinggalan Megalitik Kecamatan Parado dengan Tinggalan Megalitik Sejenis di Sumbawa}

Tinggalan megalitik yang terdapat di Kecamatan Parado pada dasarnya tidak berbeda dengan tinggalan megalitik lain yang ditemukan di wilayah Kepulauan Sumbawa. Tinggalan megalitik di kepulauan ini tersebar di beberapa lokasi antara lain di Kecamatan Moyo Hulu, Kabupaten Sumbawa, Kecamtan Hu'u, Kabupaten Dompu, serta Kecamatan Donggo, Kabupaten Bima. Tinggalan tersebut antara lain kubur bejana batu, lumpang batu, arca dan relief megalitik, dolmen, dan tutup bejana batu atau oleh masyarakat parado dikenal sebagai tabe. Kesamaan bentuk dan fungsi antara tinggalan megalitik di Kecamatan Parado dengan tinggalan megalitik yang tersebar di beberapa lokasi yang telah disebutkan menunjukkan adanya hubungan yang penulis kaji sebagai berikut.

1) Hubungan berdasarkan bentuk dapat dilihat dari kesamaan bentuk tinggalan. Salah satu contoh tinggalan yang menunjukkan adanya hubungan antar tinggalan megalitik di Kepulauan Sumbawa yaitu kubur atau bejana batu. Bejana Batu atau Widu tipe 1 dan tipe 2 berbentuk batuan monolit yang dilubangi pada bagian tengahnya, hanya saja lubang yang terdapat pada Widu tipe 1 berbentuk silindris, sedangkan lubang yang terdapat pada Widu tipe 2 berbentuk persegi panjang. Pembuatan bejana batu atau widu dengan cara melubangi batuan monolit juga dapat dilihat pada tinggalan Situs Oi Busi, Kecamatan Hu'u, Kabupaten Dompu. Situs Oi busi juga memiliki bentuk kubur lain yang berbentuk susunan batuan dalam tanah. Bentuk terebut menyerupai kubur bejana batu atau widu tipe 4 yang terdapat di Kecamatan Parado. Bentuk bejana batu atau widu yang lain di Kecamatan Parado yaitu Bejana Batu atau Widu tipe 3. Widu 
tipe ini juga ditemukan di beberapa tempat di Kepulauan Sumbawa antara lain di Situs Bumi Pojo, Situs Karombo Dudu dan Situs Tere Rade, Kecamatan Donggo, Kabupaten Bima.

Teknik pembuatan bejana batu atau widu dengan cara menyusun, melubangi atau bahkan membentuknya penulis asumsikan bahwa budaya tersebut berkembang cukup lama di kepulauan ini. Berdasarkan bentuknya, widu tipe 4 yang berupa susunan batu pada liang silindris merupakan jenis widu yang berkembang pertama kali di Kepulauan Sumbawa. Widu tipe ini memiliki bentuk yang sederhana dibandingkan widu tipe lain. Teknik pembuatan dengan cara menyusun batuan pada liang silindris tampak lebih mudah dilakukan daripada melubangi atau bahkan membentuk batuan menyerupai tabung. Dalam kajian arkeologi, tinggalan yang berbentuk sederhana dikatakan lebih tua daripada tinggalan dengan bentuk yang kompleks. Hal ini menunjukkan bahwa pola pikir masyarakat pendukung budaya tersebut masih terbatas dan lebih ditujukan pada aspek fungsi.

Tinggalan lain yang menunjukkan adanya hubungan antara tinggalan megalitik di Kecamatan Parado dengan tinggalan megalitik di Kepulauan Sumbawa yaitu relief-relief yang terdapat di Arca Megalitik Wadu Wawi. Reliefrelief tersebut antara lain relief manusia kangkang, relief perahu, dan relief binatang. Relief-relief ini juga ditemukan di Situs Batutering dan Situs Tarakin, Kecamatan Moyo Hulu, Kabupaten Sumbawa. Kesamaan bentuk dan fungsi relief yang dipahatkan pada wadah kubur menunjukkan bahwa masyarakat di kepulauan ini memiliki kepercayaan yang serupa.

Kesamaan bentuk antara tinggalan megalitik di Kecamatan Parado dengan tinggalan megalitik sejenis di Kepulauan Sumbawa karena kemungkinan tinggalan tersebut berasal dari masa yang sama. Tinggalan fragmen perunggu pada Situs Kopa'ncui menunjukkan bahwa masyarakat pendukung kebudayaan megalitik di Kepulauan Sumbawa pada saat itu sudah mengenal pembuatan benda-benda logam. Masa logam awal atau paleometalik di Indonesia, khususnya di Indonesia bagian timur, berkembang sekitar 200 SM sampai 1000 M. Masa ini ditandai dengan adanya penguburan dalam sebuah wadah atau tempayan dan umumnya disertai bekal kubur seperti manik-manik, gelang dan artefak-artefak logam (Bellwood, 2000: 425-426). Hal menarik terdapat pada kubur-kubur di Situs So Langgodu. Tinggalan berupa belati besi dan keramik ditemukan pada kubur duduk situs tersebut (Kusumawati, 2010: 524; Kusumawati dkk, 2013: 9-29). Berdasarkan temuan tersebut tinggalan megalitik di Kepulauan Sumbawa, khususnya di Kecamatan Parado dapat dimasukkan pada periode masa logam akhir.

2) Hubungan berdasarkan fungsi dapat dilihat dari kesamaan fungsi tinggalan. Fungsi tinggalan megalitik yang bersifat Death Monument di Kepulauan Sumbawa khususnya di Kecamatan Parado tidak dapat dijelaskan secara pasti, namun berdasarkan analisis fungsi yang telah penulis paparkan sebelumnya, fungsi tinggalan megalitik yang terdapat di Kecamatan Parado maupun di Kepulauan Sumbawa mengindikasikan adanya hubungan sosial seperti religi atau kepercayaan, status sosial maupun caracara hidup masyarakat pendukung kebudayaan megalitik tersebut.

Religi atau kepercayaan pada masyarakat megalitik dapat dilihat melalui perlakuan masyarakat tersebut terhadap individu yang telah meninggal. Masyarakat pendukung tradisi megalitik percaya bahwa arwah nenek moyang yang telah meninggal, masih hidup di 
dunia arwah. Masyarakat ini juga percaya bahwa keamanan, kesehatan, kesuburan dan lain-lain sangat ditentukan oleh bagaimana perlakuan mereka terhadap arwah nenek moyang mereka yang telah meninggal. Perlakuan baik terhadap arwah leluhur ini ditunjukkan dengan membuatkan wadah kubur sebagai sarana transportasi bagi arwah untuk mencapai alam yang jauh letaknya. Wadah kubur tersebut antara lain berupa peti batu, dolmen, sarkofagus, bejana batu atau kalamba, waruga dan pandusa (Sukendar, 1996/1997: 1-2; Wiradnyana, 2009: 174175).

Bejana batu atau widu yang difungsikan sebagai wadah kubur mengindikasikan bahwa masyarakat pendukung kebudayaan megalitik di Kepulauan Sumbawa pada masa itu sudah mengenal kepercayaan adanya kehidupan setelah meninggal. Pemanfaatan widu sebagai wadah kubur mulai berakhir pada saat masuknya Islam di Bima. Hal ini terlihat pada kubur-kubur di Situs Gajah Mada, Kecamatan Hu'u, yang berbentuk menyerupai batu temu gelang dengan menhir di bagian tengahnya dan sebagian kubur yang sudah memakai nisan layaknya makam Islam (Yuliati, 2004: 81).

Selain kubur-kubur yang telah disebutkan, benda monumental seperti arca megalitik dan relief-relief pada tinggalan megalitik menunjukkan bahwa masyarakat pendukung kebudayaan megalitik tersebut mempercayai adanya kehidupan lain. Relief antropomorpik, perahu dan binatang yang dianggap memiliki fungsi sebagai simbol magis dapat diasumsikan bahwa arca megalitik dan relief-relief yang berada di situs-situs kepulauan ini merupakan simbol individu yang meninggal atau pengawal arwah individu tersebut menuju tempat bersemayamnya arwah. Benda monumental tersebut tidak hanya menujukkan sistem kepercayaan, namun juga mengindikasikan adanya status sosial. Pendirian benda monumental tersebut pada umumnya berkaitan dengan usaha para pemimpin, kepala desa atau ketua adat untuk menjaga harkat dan martabat para pemimpin tersebut (Sukendar, 1996/1997: 1). Usaha ini dapat dilihat pada Situs Wadu Wawi dan Situs Lutuk Peti yaitu dengan menempatkan arca megalitik dan relief di dekat atau pada kubur-kubur batu, sehingga arca megalitik dan relief yang ditempatkan dekat atau pada kubur-kubur tersebut menunjukkan bahwa individu yang dimakamkan memiliki kedudukan penting.

Tingginya status sosial juga dapat dilihat pada tinggalan yang dianggap sebagai kopa atau telapak kaki. Tinggalan berupa kopa ini ditemukan di Situs Kopa'ncui, Kecamatan Hu'u, Kabupaten Dompu dan Situs Doro Asi, Kecamatan Parado, Kabupaten Bima. Kopa ini difungsikan sebagai penanda wilayah oleh tokoh tertentu, seperti contoh Bibano yang berada di Situs Doro Asi. Penandapenanda wilayah tersebut menunjukkan adanya legitimasi kekuasaan pada masa itu. Masyarakat Bima percaya bahwa kekuasaan pada masa itu diperintah oleh Ntjuhi.

Hubungan tinggalan megalitik di Kecamatan Parado dengan tinggalan megalitik lain di Kepulauan Sumbawa, selain sistem religi atau kepercayaan dan status sosial, juga menunjukkan cara-cara hidup masyarakat pendukung kebudayaan megalitik tersebut. Tinggalan berupa lumpang batu yang pada umumnya difungsikan untuk menumbuk biji-bijian, mengindikasikan bahwa masyarakat pada masa itu sudah mengenal bercocok tanam. Selain lumpang batu, relief-relief seperti relief perahu dan anjing pada tinggalan megalitik juga menunjukkan adanya kegiatan lain selain bercocok tanam. Relief perahu mengindikasikan bahwa 
masyarakat pendukung kebudayaan megalitik di Kepulauan Sumbawa sudah mengenal transportasi air. Transportasi ini pada umumnya digunakan oleh nelayan untuk menangkap ikan, bahkan juga digunakan sebagai trasnportasi antarpulau. Aktivitas menangkap ikan di laut oleh nelayan pada masa itu didukung dengan adanya temuan di Situs Nangasia yang berlokasi di pesisir Pantai Hu'u. Temuan-temuan tersebut antara lain yaitu benda-benda gerabah dengan bentuk yang masih utuh maupun pecah seperti tempayan, mangkok, cobek, dan cawan, temuan berupa manik-manik dari batu kornelin, dan temuan sisa-sisa makanan yang berupa tulang binatang darat dan tulang binatang laut seperti penyu, ikan dan kerang (Kusumawati, 2009b: 128129).

Relief lain yang menunjukkan cara-cara hidup masyarakat pendukung kebudayaan megalitik di Kepulauan Sumbawa yaitu relief binatang, khususnya relief anjing. Anjing merupakan salah satu binatang yang sangat berperan dalam kehidupan seharihari, khususnya pada masyarakat pendukung tradisi megalitik. Anjing dalam kehidupan sehari-hari digunakan untuk menjaga rumah dan sawah atau ladang. Binatang ini peka terhadap gejala-gejala yang tidak seperti biasanya, misalnya saat ada kehadiran orang lain di sekitar rumah. Anjing juga akan menolong seandainya ada binatang yang tidak dikenalnya seperti babi hutan atau binatang buas lainnya. Adanya keakraban antara manusia dengan anjing menjadikan binatang ini sangat berpengaruh dalam kreativitas seni pola hias pada tinggalan megalitik, sehingga motif anjing, sebagai contoh masyarakat Sumba, dipahatkan pada penji atau menhir dan kubur dolmen (Kusumawati dan Sukendar, 2003: 87).

Masyarakat di Kecamatan Parado hingga saat ini masih memanfaatkan anjing dalam kehidupan sehari-hari. Binatang ini umumnya digunakan untuk menjaga sawah atau ladang dari hama seperti babi hutan dan kera. Selain digunakan untuk menjaga sawah dan ladang, anjing juga masih digunakan untuk berburu. Jika dikaitkan dengan tinggalan megalitik di kecamatan ini yaitu relief binatang di Situs Wadu Wawi, binatang anjing bagi masyarakat pendukung kebudayaan megalitik di Kecamatan Parado penulis asumsikan memiliki peran yang sama. Binatang ini selain digunakan untuk menjaga sawah atau ladang, juga digunakan untuk berburu, sehingga selain bercocok tanam dan menangkap ikan di laut, masyarakat pendukung kebudayaan megalitik di Kepulauan Sumbawa juga berburu untuk memenuhi kebutuhan sehari-hari.

\section{Simpulan}

Berdasarkan hasil penelitian yang telah diuraikan sebelumnya, dapat ditarik suatu kesimpulan dari hasil penelitian yang telah dilakukan. Beberapa simpulan yang diperoleh yaitu sebagai berikut.

a. Kecamatan Parado memiliki tinggalan megalitik dengan bentuk yang beraneka ragam. Tinggalan tersebut antara lain berupa kubur atau bejana batu, lumpang batu, dolmen, dan parabo. Sebagian besar tinggalan tersebut telah hancur, namun masih bisa dilihat bahwa tinggalan tersebut memiliki kesamaan bentuk dengan tinggalan megalitik lain di Kepulauan Sumbawa. Adapun tinggalan megalitik ini difungsikan sebagai benda sakral dan profan pada masa lalu seperti sebagai wadah kubur, tempat menaruh sesaji, dan sebagai penanda wilayah.

b. Kesamaan bentuk dan fungsi tinggalan megalitik di Kecamatan Parado dengan tinggalan megalitik sejenis di Kepulauan Sumbawa dikarenakan tingalan tersebut saling berhubungan dan berasal dari kebudayaan yang sama. Salah satu contoh yaitu bentuk-bentuk 
bejana batu yang difungsikan sebagai wadah kubur dan lumpang batu yang difungsikan sebagai wadah untuk menumbuk. Kebudayaan ini berkembang cukup lama yaitu dari masa logam dan berakhir pada masa masuknya Islam di Bima.

\section{Daftar Pustaka}

Ambarawati, Ayu. 2012. "Potensi Arkeologi Situs Dorobata Kabupaten Dompu NTB". Forum Arkeologi. No. 3 November 2012. Hal 251-266. Denpasar: Balai Arkeologi Denpasar.

Bellwood, Peter. 2000. Prasejarah Kepulauan Indo-Malaysia. Jakarta: PT Gramedia Pustaka Utama.

Endraswara, Suwardi. 2003. Metodologi Penelitian Kebudayaan. Yogyakarta: Gajah Mada University Press.

Kusumawati, Ayu dan Gede, Dewa Kompiang. 2009. "Penelitian Situs Donggo, Kecamatan Donggo, Kabupaten Bima, Nusa Tenggara Barat". Laporan Penelitian Arkeologi, No. 5. Denpasar: Balai Arkeologi Denpasar.

Kusumawati, Ayu dkk. 2013. "Ekskavasi dan Survey di Kecamatan Hu'u, Kabupaten Dompu". Laporan Penelitian Arkeologi, No. 02. Denpasar: Balai Arkeologi Denpasar.

Kusumawati, Ayu dan Sukendar, Haris. 2003. Sumba: Religi dan Tradisinya. Denpasar: Balai Arkeologi Denpasar.

Kusumawati, Ayu. 1999. "Pola Hias Peninggalan Megalitik Sumbawa: Hubungan dengan Alam Kematian". Forum Arkeologi, No. II Desember
1999. Hal 13 - 27. Denpasar: Balai Arkeologi Denpasar. 2009a. "Tinjauan Difusi

Budaya Atas Tinggalan Arkeologi Donggo, Kabupaten Bima, NTB" Forum Arkeologi, No. II Juli 2009. Hal 75-92. Denpasar: Balai Arkeologi Denpasar. 2009b. "Temuan Situs Gerabah di Nangasia, Kabupaten Dompu". Forum Arkeologi, No. III Oktober 2009. Hal 127-143. Denpasar: Balai Arkeologi Denpasar.

2010. "Budaya Austronesia di Dompu Arti dan Maknanya". Forum Arkeologi, TH. XXIII. No. 3 November 2010. Hal 511-532. Denpasar: Balai Arkeologi Denpasar.

Simanjuntak, Truman. 1999. Metode Penelitian Arkeologi. Jakarta: Pusat Penelitian Arkeologi Nasional

Sukendar, Haris. 1996/1997. Album Tradisi Megalitik di Indonesia. Jakarta: Departemen Pendidikan dan Kebudayaan.

Sunarya, I Nyoman. 2006. "Penelitian Situs Warukali, Dompu, Nusa Tenggara Barat". Berita Penelitian Arkeologi. Hal 27-47. Denpasar: Balai Arkeologi Denpasar.

Wiradnyana, Ketut. 2009. "Wadah dan Tanda Kubur, Sebuah Simbol Dalam Tradisi Megalitik Masyarakat Nias Selatan". Sangkakala. No. 24 November 2009. Hal 170 - 180. Medan: Balai Arkeologi Medan.

Yuliati, Citha. 2004. "Nangasia dalam Perjalanan Waktu". Forum Arkeologi, No.II November 2004. Hal 72 - 93. Denpasar: Balai Arkeologi Denpasar 